378.147::811.163.41(430)

https://doi.org/10.18485/msc_saopstenja.2018.48.1.ch22

Јелена Д. АНЋЕЛКОВИЋ * Unversität Hamburg

Institut für Slavistik
Прегледни рад

Примљен: 06. 11. 2018.

Прихваћен: 03. 12. 2018.

\title{
ПРОУЧАВАЊЕ СРПСКОГ ЈЕЗИКА, КЊИЖЕВНОСТИ И КУЛТУРЕ НА ИНСТИТУТУ ЗА СЛАВИСТИКУ УНИВЕРЗИТЕТА У ХАМБУРГУ
}

\begin{abstract}
У раду се кроз новији историјат представља развој српског лектората на Институту за славистику у Хамбургу. Развој се прати на временском одсечку од седамдесетих година до актуелног стања. Затим се излаже структура студија у оквиру којих се представљају појединачни курсеви на којима се проучавају српски језик, књижевност и култура. Наводе се методички приступи, наставна средства, проблеми који прате извођење наставе и могући начини њиховог превазилажења. У завршном делу износе се перспективе лектората.

Кључне речи: историјат лектората, актуелна ситуација, структура студија, курсеви језика, књижевности и културе, проблеми у настави и њихово превазилжење, перспективе.
\end{abstract}

Овогодишњем Међународном састанку слависта у Вукове дане претходио је скуп у Андрићграду, у организацији МСЦ-а, а под покровитељством Министарства културе. Међународни славистички центар је препознао важност оваквог скупа и за округлим столом Андрићевог института окупио је лекторе са страних катедара. Поред њих су у дискусији учествовали професори и лектори МСЦ-а, као и представник Министарства културе, које је показало жељу да се рад лектората подржи и потпомогне и из Србије. Изузетно важна дискусија отворила је широко поље проблема који су били везани како за технички део реализације (недостатак одговарајућих кадрова, уџбеника и опреме: звучне лабораторије, интернет конекције, пројектора, паметних табли) тако и за методику наставе (мешовите групе, нејасно дефинисани исходи, недовољан број часова конверзације). О сврсисходности скупа говори чињеница да су се већ кроз дискусију за неке од проблема налазила решења. На овај начин су сви учесници скупа стекли јасну слику актуелног стања које

*jelena.andelkovic@uni-hamburg.de 
захтева хитне промене. Као закључак наметнула се потреба за умрежавањем лектора који би на тај начин могли да размењују материјале, идеје и искуства, као и чвршћа сарадња са државним институцијама, што би побољшало квалитет наставе.

Правац који је имала конструктивна дискусија у Андрићграду навео ме је на извесне измене у садржини излагања на конференцији. С обзиром на то да су поред професора и лектора активни учесници били и представници важних државних институција које су показале интересовање и жељу да подрже рад лектората, сматрала сам важним истицање горућих питања везаних за опстанак српског лектората на Институту за славистику у Хамбургу.

\section{Гашење лектората}

Алармантност ситуације у пракси најбоље илуструју бројке. Србија је, пре политички турбулентних времена, на територији Немачке имала седамнаест лектората. Данас је то једва бројиво. Осим Хамбурга, још једино у Келну ради наш лектор. Уколико би се истраживало, наишло би се на податке да се још на неколико универзитета у Немачкој поред бошњачког и хрватског проучава српски, али је питање: ко су лектори и на који начин се представљају српски језик, књижевност и култура. Често се као разлог за гашење српских лектората наводе агресивне политике других земаља. Но, задржимо се на ономе на шта сами можемо да утичемо, како би се нешто променило набоље. Досадашње стање показује потпуно одсуство свести о значају рада лектората. Оно што улива наду за будућност су управо округли сто у Андрићграду и скуп слависта у Тршићу.

Лектори су важни за одржавање везе између не само два универзитета него и две земље. Њихов задатак увелико превазилази извођење наставе, јер су стране катедре центри ширења културе у дијаспори, нека врста жаришта око којих би требало да се окупља културна елита која са матицом чини целину. Захваљујући изванредним напорима професора Роберта Ходела, везе између Београда и Хамбурга се учвршћују, а блиска сарадња се остварује честим гостовањима предавача из Србије, међу којима су били професори Јован Делић, Бошко Сувајџић, Тихомир Брајовић, Драган Бошковић, Драгана Вукићевић, доценткиња Мина Ђурић, али и значајни писци, попут Драгана Великића. Ова предавања заправо прерастају у књижевне вечери отвореног типа, којима поред студената славистике присуствују и представници конзулата, културни радници, уметници, људи из различитих бранши које окупља љубав према српском језику, књижевности и култури. 


\section{Развој лектората}

Од 1968. до 2002. године је као лектор, а затим као доцент на Институту за славистику у Хамбургу, радила Олга Елермајер Животић. Захваљујући повољној клими на универзитету, како она каже, а ја сам сигурна и њеним изузетним личним залагањем, поред језика почиње да се изучава књижевност. Прво је додат Курс I увода у књижевност, а затим и Курс II, на коме се проучавају најзначајнија дела српскохрватских писаца попут Црњанског, Андрића, Селимовића и Крлеже. Тиме се почетна половина лектората, коју је Елермајер Животић наследила од свог претходника, увећава на цело лекторско место, а курс језика прераста у озбиљне студије. Њу наслеђује Олга Стојановић, хамбуршки студент, која као лектор ради наредне две године. До 2004. предмет задржава назив српскохрватски језик, а затим катедра одлучује да се босанском, хрватском и српском дају статуси посебних језика, који захваљујући заједничкој новоштокавској основи могу да се изучавају као један, БХС језик. Промене настају и у самој кадровској структури. Лекторат се уситњава, тако да нови лектор из Сарајева преузима само половину норме. Преостали део часова дели се између два хонорарна лектора. Тај посао су обављали „људи у пролазу”, без намере и могућности да се на Институту задрже. Често нису успевали да квалитетом одговоре висини задатка који се пред њих постављао. Настава се под наметнутим околностима тешко организује, с обзиром на то да један курс од шест часова реализују два лектора. Оваква одлука деканата наилази на негодовање и студента и наставног особља. Упркос лошем решењу које битно утиче на квалитет наставе, описана ситуација траје наредних десет година. Србија за то време нема лектора у Хамбургу, односно некога ко је наш универзитет доживљавао као своју матичну кућу. То је ситуација коју сам дошавши на Институт 2014. затекла. Након три семестра хонорарног рада, на захтев студената и шефа Катедре, деканат је одлучио да уговором на две године реши озбиљне наставне и кадровске проблеме тако што је норма укрупњена, и мени додељена половина лекторског места. Овде се долази до актуелног стања, до онога што је тренутно и што ће важити до краја зимског семестра 2018/19, нажалост без могућности да се предвиди будуће.

Гашење малих (по броју студената) лектората и формирање јаке германистике је правац који се наслућује из потеза који Универзитет у Хамбургу повлачи. На студије германистике се данас гледа као на „престижне”, уколико нам као репер послужи изузетно висока улазна квота за упис и број заинтересованих студената. По овим критеријумима славистика се налази на маргинама и не завређује пажњу челника Универзитета који се воде једино бројкама.

Од 2017. године све библиотеке, које су се налазиле у склопу катедара, измештене су и физички одвојене. На њихов рачун формирана је једна, централна, која има јединствен извор финансирања. У таквој расподели буџета, јасно је да библиотека Катедре за славистику има изузетно скромне могућности у поређењу са германистиком. Важно је напоменути да је наша би- 
блиотека до сада изванредно радила и да поседује изузетно богат књижевни фонд, који се непрекидно увећава најсавременијим насловима српске књижевности, пре свега захваљујући књигама које Народна библиотека Србије шаље у Хамбург. Да ли судбина библиотека најављује оно што очекује и наш лекторат уколико се не појави подршка из матичне земље?

\section{Структура студија}

Поред српског језика, данас се на Катедри за славистику у Хамбургу могу изучавати, уз доминантну русистику која има највећи број студената, још и полонистика и бохемистика. Не постоје курсеви језика, већ се српски проучава у оквиру различитих студијских група, од којих зависе обавезе и активности студената, као и недељна динамика наставе. При упису се понуђени БХС може одабрати за главни (Hauptfach) или изборни (Nebenfach) предмет. Бројнију групу сачињавају студенти који поред руског, пољског или чешког, бирају БХС за други словенски језик. За БХС као главни предмет се најчешће одлучују студенти чији родитељи долазе са територије бивше Југославије, дакле воде порекло са ових простора. Они имају два матерња језика. Двојезичност која их карактерише не упућује на закључак да је њихов ниво знања оба језика исти. Немачки су усвајали у средини у којој су одрастали, али пре свега кроз школски систем, учећи језички стандард. Српски језик су слушали у породици, учећи нестандардну варијанту говора својих родитеља. Додатна отежавајућа околност је и интерференција, с обзиром на то да су непрекидно изложени снажном утицају немачког језика. Често лектори имају највише проблема управо у оваквим случајевима, пошто је изузетно тешко исправити грешке научене у најранијем детињству, под чијим утицајима они остају и даље, комуницирајући у кругу породице. Отуда на препоруку лектора и они, иако поседују богат лексички фонд, крећу са проучавањем језика од почетка, што додатно компликује организовање наставе у мешовитим групама.

Покушај превазилажења проблема мешовитих група је ослобађање таквих студената обавеза похађања наставе почетног курса (Einführungskurs), на коме се усвајају основни појмови комуникације, а чије познавање студенти доказују тестирањем (Einstufungstest). Студенти који за главни предмет одаберу БХС у оквиру своје студијске групе похађају:

- Предавања и семинаре из лингвистике, која води проф. Марион Краузе, а на којима се изучава структура језика, дакле фонетика, фонологија, морфологија и синтакса. Циљ је да се уочи концепт језичког система и тиме формира основа за даље научно бављење поменутим језицима, како у оквиру лингвистике тако и књижевности.

- Предавања и семинаре из књижевности, која води проф. Роберт Ходел, а чији садржај уводи фундаментална питања књижевних студија, као што је на пример теорија наратора. Корпус који се анали- 
зира је на циљаном језику, често у ћириличној варијанти, што значи да студенти читају оригиналне текстове, понекад уз помоћ превода. Неки од обрађиваних романа су: Сеобе, Травничка хроника, Дервиш и смрт. Уз поменуте класике у плану су и дела савремених писаца попут Драгослава Михаиловића или Драгана Великића.

Уз наставу из лингвистике и књижевности организује се рад са туторима, старијим студентима који су градиво савладали у неком од претходних семестара.

- Курсеве језика на основном (Einführungskurs), средњем(Aufbaukurs I и II) и вишем нивоу (Vertifungskurs) које изводимо Сеад Поробић и ја, дакле лектори матерњи говорници оба језичка варијетета (и ијекавице и екавице) уз употребу оба писма. Групе на основном нивоу броје око 20 студената. Међутим, овај број не даје објективну слику. Свега пет-шест студената настави са учењем језика. Остали захваљујући Болоњском систему задовољавају форму и на оваквим курсевима сакупљају неопходне бодове. Поменуте тешкоће на које лектор наилази у раду са мешовитим групама могуће је превазићи индивидуалним приступом управо због малог броја студената. За лектора на оваквим курсевима представљало би посебан изазов задовољити исходе, али их све треба претходно јасно дефинисати. Поставља се питање да ли курсеви језика служе да у пракси потврде оно о чему се из лингвистике говорило, или је циљ да студенти проговоре и буду у стању да остваре комуникацију на различитим нивоима. Пошто се језик проучава у оквиру студијских група и акценат мора да буде на дескриптивној граматици као полазишту, тешко је у задати недељни фонд, који варира од два до три двоча$\mathrm{ca}$, уклопити неопходну комуникацију, која је за студенте и најбоља мотивација за учење. Највећа вештина лектора огледа се управо у изналажењу баланса између ова два приступа.

- Преводилачки курс који полазницима отвара и неке могућности везане за посао, а за који постоји интересовање и ван студијских оквира.

- Културну историју (Landeskunde), курс подељен на предавања која на историјској подлози, и то од доласка Словена на Балкан до Берлинског конгреса, базирају причу о најзначајнијим сегментима културе у Босни, Хрватској и Србији: о архитектури, иконопису, сликарству, музици, отварању школа, библиотека, музеја, позоришта, стварању културних институција као и најзначајнијим људима са овог простора, који су својим радом допринели развоју културе. Други део курса су вежбе које прате развој језика и писма од Моравске мисије до Вукове реформе. На вежбама се анализирају оригинални текстови писани у доба о коме се говорило на предавању. Курс нуди могућност употребе различитих метода и средстава (филмова, илустрација, фотографија, звучних записа) који у великој мери повећавају пријемчивост садржаја. 
Овако изложена структура студија има и свој природни наставак управо овде, у Србији. Тронедељна школа језика је обавезни део практичне наставе. Студенти имају могућност да доласком у Београд и похађањем курса побољшају своја језичка знања и вештине, али и да се кроз бројне излете и обиласке приближе српској култури и традицији о којој су до тада само слушали или учили преко литературе. Ипак, нема боље од показне методе. Приликом обиласка поставке у Народном музеју, студенткиња која је са мном допутовала из Хамбурга усхићено ми се обратила: „Видите, па то је Темнићки натпис чији текст ја познајем!"

\section{Перспективе}

Упркос добро структуираним студијама, одличном наставном кадру, савременим методама, добрим условима за рад и одлично опремљеној библиотеци, број студента србистике и уопште славистике опада. Судећи на основу претходних излагања колега, овај тренд се уочава на свим страним катедрама, чак и на матичним универзитетима на којима се српски језик проучава као матерњи. Отуда се поставља питање како србистику учинити атрактивнијом. Једна од могућности је двоструки мастер, који би за студенте из Србије могао да буде интересантан, а за катедру изузетно користан. Тиме би се повећао број студената и побољшао кавлитет наставе. Након основних студија завршених у Србији, студенти би своје мастер студије наставили у Хамбургу. Ова идеја је тренутно у фази реализације између факултета у Београду и Келну, а степен успешности пројекта би могао да утиче на будућу сарадњу и са Хамбургом. Неки од проблема који се намећу су разлика у структури студија (на нашим универзитетима основне студије трају четири, а мастер годину дана, док је у Немачкој тај однос другачији: три године основних и две године мастер студија), висок степен знања немачког језика који би студенти морали да имају како би пратили наставу, уклапање предмета двају универзитета и стварање нових модула. Бројне потешкоће које се у овако озбиљним пројектима јављају могу се превазићи благовременом припремом студената и огромном вољом и залагањем професора, доцената и сарадника са обе стране, а модел који је Келн у сарадњи са Београдом развио могао би уз измене да следи и Хамбург. 
Jelena D. Anđelković

DER AKTUELLE ZUSTAND DES SERBISCHES LEKTORAT AN DER UNVERSITÄT HAMBURG

Zusammenfassung

Der Aufsatz beschäftigt sich mit dem Thema: Der aktuelle Zustand des serbisches Lektorats an der Universität Hamburg. Zuerst zeigt er die Entwicklung des Lektorats von 1968 bis heute. Danach sind Studienstruktur, Module und Kurse (Sprachkurs, Übersetzung, Linguistik, Literatur, Landeskunde) beschteribt worden. Das Thema ist aus verschiedenen Blickwinkeln beleuchtet, die die wichtigste Probleme beim Lektorat zeigen. Der Text stellt eine Frage vor: Was man in der Zukunft erwarten kann? Am Ende ist die Perspektive vorgestellt worden.

Stichwörter: die Entwicklung des Lektorats, der aktuelle Zustand, Studienstruktur, Kurse, Probleme, Perspektive. 